Al-Bidayah : jurnal pendidikan dasar Islam

Volume 13, Number 1, June 2021

ISSN: 2549-3388 (online)

Available online at https://jurnal.albidayah.id

Submitted: February 3, 2021, Accepted: June 26, 2021

\title{
UNDERSTANDING THE CONCEPT OF SPUR DIMENSIONS REVIEWED BY THE TERMS OF GENDER DIFFERENCES AND ABILITY CATEGORIZED BY STUDENTS AT MADRASAH IBTIDAIYAH
}

\author{
Hajra Yansa $^{1}$, Murniati $^{2}$, Nurrahmah $^{3}$, Nurhayati $^{4}$, Ani Fitriyani $^{5}$ \\ Yogyakarta State University, Indonesia ${ }^{1,4}$, Palopo Cokroaminoto University, Indonesia ${ }^{2}$, \\ Semarang State University, Indonesia ${ }^{3}$, Madrasah Ibtidaiyah Al Wathoniyah \\ Cikedunglor, Indonesia ${ }^{5}$ \\ E-mail: hajrayansa.2019@student.uny.ac.id ${ }^{1}$, murniaticokro@uncp.ac.id ${ }^{2}$, \\ nurrahmah17@students.unnes.ac.id ${ }^{3}$, nurhayati6pasca.2018@student.uny.ac.id ${ }^{4}$, \\ anifitriyani44@gmail.com ${ }^{5}$
}

DOI: 10.14421/al-bidayah.v13i1.622

\begin{abstract}
These gender differences and abilities categorized by students at Madrasah Ibtidaiyah (Islamic Elementary School in the Ministry of Religious Affairs, Indonesia) can understand the concept of SPUR dimension fractions (Skills, Property, Uses, and Representation) that is the focus of this study. Presently, it is to answer the study's neediness about gender differences in math performance recommended by the previous studies. To offer the novelty about the measurement of conceptual understanding in four dimensions because one dimension is not relevant to describe students' understanding comprehensively and deeply of mathematical concepts. This study was a qualitative descriptive that relies on the analysis of test participants' answers; it consists of three male students and three female students representing the high, medium, and low ability categories at Madrasah Ibtidaiyah of Indramayu Regency. The students' participant is determined by purposive sampling. The analysis of the test participants' answers demonstrated the ability to understand the concept of fractions in the SPUR dimension of equality between male and female students in the same ability category. However, the students at every level of ability to achieve a different dimension. Male and female students in the high category achieved the dimensions of skills and property. Male and female students in the medium and low categories achieved skills. High-ability students and the medium category experienced an integer bias error using the integer property infractions. They perform arithmetic operations in the numerator and denominator separately as if they were independent integers. For this reason, students need to develop an understanding of concepts, especially on the dimensions of fraction properties, applications, and their representations, without being influenced by gender stereotypes. This development of understanding can be done through SPUR dimensional exercises that avoid gender bias, and teachers establish communication mathematics teaching in the classroom to engage students in both men and women
\end{abstract}

Keywords: concept understanding of SPUR; fractions; gender; madrasah ibtidaiyah; mathematical ability

\section{INTRODUCTION}

In the 21 st century is expected that students literacy mathematics through understanding the whole concept. ${ }^{1}$ Because understanding the concept is one of five stalks that build proficiency mastery prowess mathematically based illustration Kilpatrick and

\footnotetext{
${ }^{1}$ Koeno Gravemeijer et al., "What Mathematics Education May Prepare Students for the Society of the Future?," International Journal of Science and Mathematics Education 15 (2017): 105-23, https://doi.org/10.1007/s10763-017-9814-6.
} 
Swafford Kilpatrick dan Swafford. ${ }^{2}$ Also regarded as the main factors that affect students' mathematics learning achievement. ${ }^{3}$ Students with a good understanding of the concept will organize knowledge into a single continuous and intact. They can use the concept are responsive, adaptable, and able to connect new concepts with the concepts that have been studied previously. ${ }^{4}$

In the last two decades, measuring the ability to understand mathematical concepts in several dimensions (multi-dimensional) has been widely an incentive like a new perspective that produces intact and depth measurements. ${ }^{5}$ The multi-dimensional and unidimensional difference is illustrated in Figures 1 and 2. Figure 1 only shows one side, while Figure 2 shows a three-dimensional building. The building is likened to the gradation of students' abilities that the teacher tries to understand through measurement, seen from any side that clearly shows students' understanding of mathematical concepts. This description is what is meant by a complete and deep understanding of the concept.

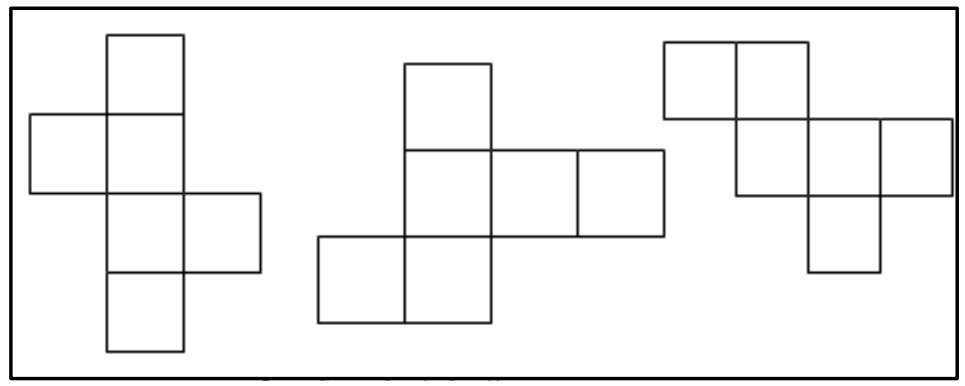

Figure 1

Unidimentional

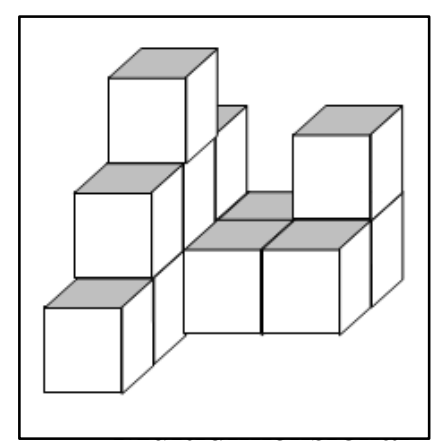

Figure 2

Multidimensional

Weldeana said that the measurement of a complete understanding of mathematical concepts should be viewed from four dimensions: skills, properties, applications (uses),

2 National Council of Teachers of Mathematics (NCTM), "Principles to Actions : Ensuring Mathematical Success for All (Executive Summary)" (NCTM, 2014), https://www.nctm.org/uploadedFiles/Standards_and_Positions/PtAExecutiveSummary.pdf.

${ }^{3}$ Kay Achmetli, Stanislaw Schukajlow, and Katrin Rakoczy, "Multiple Solutions for Real-World Problems, Experience of Competence and Students' Procedural and Conceptual Knowledge," International Journal of Science and Mathematics Education 17, no. 8 (2018): 1605-25, https://doi.org/10.1007/s10763018-9936-5.

${ }^{4}$ Audrey De Zeeuw, Tara Craig, and Hye Sun You, “Assessing Conceptual Understanding in Mathematics," Proceedings - Frontiers in Education Conference, FIE, 2013, 1742-44, https://doi.org/10.1109/FIE.2013.6685135.

${ }^{5}$ Alina Han Ron Khaw and Berinderjeet Kaur, “A Study of Mathematics Homework in Singapore Secondary Two Classrooms,” 2017, https://repository.nie.edu.sg//handle/10497/19438. 
representation (representation), or abbreviation with the acronym are SPUR. ${ }^{6}$ SPUR is claimed to overcome the measurement limitations on one dimension because it provides strong evidence of understanding ${ }^{7}$. SPUR tries to examine students' mathematical abilities from the lowest level of skill leading to the highest level, namely representation ${ }^{8}$ and allows students to communicate thought patterns. ${ }^{9}$

Dimensions SPUR harmony with the understanding of the concept is meant by NCTM, which is students' ability to understand the concepts, relationships, and mathematical operations appropriately. ${ }^{10}$ Achmetli, Schukajlow, and Rakoczy labeling students understand if it has knowledge of the concepts and principles of mathematics and finding solutions to problems in the real world or the use of mathematical applications. ${ }^{11}$ So, a strong conceptual understanding is shown by students' ability to solve problems in each dimension. ${ }^{12}$ These responses can give a complete view of the teachers regarding the students' conceptual understanding so that further preparation of activities can be carried out in class on the concepts that have not been mastered. ${ }^{13}$

The one influence on the understanding of the concept is gender difference. This statement is consistent with the finding that Patricia and Zamzam, ${ }^{14}$ female students at

${ }^{6}$ Hailu Nigus Weldeana and Desta Berhe Sbhatu, "Portfolio of Evidence : An Assessment Tool in Promoting Geometry Achievement among Teacher Education College Students," Journal of Mathematics Science and Technology Education 8223, no. 6 (2017): 1981-2004, https://doi.org/10.12973/eurasia.2017.01210a.

${ }^{7}$ Christine Suurtamm et al., Assessment in Mathematics Education Large-Scale Assesment and Classroom Assessment, Encyclopedia of Mathematics Education (Hamburg, 2016), https://doi.org/10.1007/978-94-007-4978-8_61.

8 dennise R. Thompson and Berinderjeet Kaur, "Using a Multi-Dimensional Approach to Understanding to Assess Student's Mathematical Knowledge," in Assessment in the Mathematics Classroom Yearbook 2011, Association of Mathematics Educators, ed. Berinderjeect Kaur and Wong Khoon Yoong (Singapore: World Scientific Publishing Company, 2011), 91-111.

${ }^{9}$ Risnamajasari Risnamajasari, "Profil Pemecahan Masalah Matematika Dikaitkan Dengan Aspek Multidimensi SPUR Pada Siswa Berprestasi Di SMP Islam Athirah.” (masters, Pascasarjana, 2017), http://eprints.unm.ac.id/12735/.

${ }^{10}$ National Council of Teachers of Mathematics (NCTM), "Principles to Actions: Ensuring Mathematical Success for All (Executive Summary)" (NCTM, 2014), https://www.nctm.org/uploadedFiles/Standards_and_Positions/PtAExecutiveSummary.pdf.

${ }^{11}$ Achmetli, Schukajlow, and Rakoczy, "Multiple Solutions for Real-World Problems, Experience of Competence and Students' Procedural and Conceptual Knowledge."

12 Thompson and Kaur, "Using a Multi-Dimensional Approach to Understanding to Assess Student's Mathematical Knowledge."

${ }^{13}$ Ho Thi and Minh Phuong, "On the Procedural-Conceptual Based Taxonomy and Its Adaptation to the Multi-Dimensional Approach SPUR to Assess Students ' Understanding Mathematics," American Journal of Educational Research 7, no. 3 (2019): 212-18, https://doi.org/10.12691/education-7-3-4.

14 Firda Alfiana Patricia and Kenys Fadhilah Zamzam, "Diskalkulia (Kesulitan Matematika) Berdasarkan Gender Pada Siswa Sekolah Dasar Di Kota Malang," AKSIOMA: Jurnal Program Studi Pendidikan Matematika 8, no. 2 (2019): 288, https://doi.org/10.24127/ajpm.v8i2.2057. 
the Madrasah Ibtidaiyah, made many mistakes in solving math problems than men. Various findings previously have formed stereotype gender, favouring men or more talented male subjects, including mathematics. Women are considered to have high math anxiety than men. ${ }^{15}$ This stereotype is due to the biological differences in students' brains ${ }^{16}$, leading to different thinking conceptualization and learning processes. In addition, differences in gender and categories of students' abilities affect understanding in solving mathematical problems. Putri et al. research showed that students divided into three categories: high, medium, and low level, achieving a different understanding of material concepts. ${ }^{17}$

Based on the problems that affect the achievement of conceptual understanding skills, it is necessary to pay attention to the capability of understanding the concept of students at Madrasah Ibtidaiyah on SPUR dimension about fractional material as the basic pattern of mathematical thinking based on gender and ability categories, because female and male have the mindset is very different, as well as its ability of each category. Therefore, this research is here to offer a new review of these two elements. Also, address the needs of research about gender differences in math performance previously recommended by Gherasim. ${ }^{18}$ The purpose of this research is to verify gender stereotypes that develop in society. On the other hand, the material tested in this research, namely fractions in the fifth grade at Madrasah Ibtidaiyah, its existence is essential in teaching mathematics because it functions as a prerequisite for proficiency mathematically at a

${ }^{15}$ Loredana Ruxandra Gherasim, Simona Butnaru, and Cornelia Mairean, "Classroom Environment, Achievement Goals and Maths Performance: Gender Differences," Educational Studies 39, no. 1 (February 1, 2013): 1-12, https://doi.org/10.1080/03055698.2012.663480; Monika Szczygieł, "How To Measure Math Anxiety In Young Children? Psychometric Properties Of The Modified Abbreviated Math Anxiety Scale For Elementary Children (MAMAS-E)," Polish Psychological Bulletin 50 (December 31, 2019): 303-15, https://doi.org/10.24425/ppb.2019.131003.; Usman Kamoru and Olosunde Gbolagade Ramon, "Influence of Self-Concept, Study Habit and Gender on Attitude and Achievement of Secondary School Students in Mathematics," Journal for Leadership and Instruction 16, no. 1 (2017): 49-52, https://eric.ed.gov/?id=EJ1159874.

${ }^{16}$ Siska Chindy Dilla, Wahyu Hidayat, and Euis Eti Rohaeti, "Faktor Gender Dan Resiliensi Dalam Pencapaian Kemampuan Berpikir Kreatif Matematis Siswa SMA," Journal of Medives : Journal of Mathematics Education IKIP Veteran Semarang 2, no. 1 (2018): 129, https://doi.org/10.31331/medives.v2i1.553.

${ }^{17}$ Niva Ramadhani Putri et al., "Analisis Kemampuan Pemahaman Matematik Siswa SMP Ppada Materi Segitiga Dan Segiempat," in Prosiding Seminar Nasional Matematika Dan Pendidikan Matematika Sesiomadika 2019, vol. 1, 2019, 1015-26, https://doi.org/10.22460/jpmi.v1i2.p157-170.

${ }^{18}$ Loredana Ruxandra Gherasim, Simona Butnaru, and Cornelia Mairean, "Classroom Environment, Achievement Goals and Maths Performance: Gender Differences," Educational Studies 39, no. 1 (2013): 1-12, https://doi.org/10.1080/03055698.2012.663480. 
high level. ${ }^{19}$ And as a gateway to success outside the mathematics class until in the world of work. ${ }^{20}$

\section{RESEARCH METHODS}

This study used descriptive qualitative to describe and illustrate fractions dimension SPUR based on gender differences and categories of student abilities at Madrasah Ibtidaiyah. The research subject was fifth-grade students at Madrasah Ibtidaiyah in Indramayu Regency-West Java in 2020/2021. Consists were three male and three female students as representative ability high, medium, and low category. The selection used the purposive sampling technique by determining the subject criteria, the fifth-grade students at Madrasah Ibtidaiyah who studied the concept of fractions. Students are divided into three categories based on math ranking on UAS results in 2019/2020. Data collection used a test. Data analysis was carried out by analyzing student worksheet documents. The test instrument is adapted by Thompson and Kaur ${ }^{21}$, which measured the concept of understanding fractions in the SPUR dimension (Skills, Property, Uses, and Representation), further modified by the researcher to the narration question. The four SPUR dimensions and indicators are presented below (in table 1).

Table 1

SPUR Indicators and Questions

\begin{tabular}{|c|c|c|}
\hline Dimensional & Indicator & Questions on Test Instruments \\
\hline Skills $(\mathbf{S})$ & $\begin{array}{l}\text { Using the proper } \\
\text { algorithm/working } \\
\text { steps. }\end{array}$ & Compute: $1 \frac{2}{3}: \frac{1}{6} !$ \\
\hline Dimensional & Indicator & Questions on Test Instruments \\
\hline Property $(\mathbf{P})$ & $\begin{array}{l}\text { Using mathematical } \\
\text { nature and principles } \\
\text { which underlie }\end{array}$ & $\begin{array}{l}\text { It is known that the following value: } \\
\qquad \begin{array}{r}\quad \mathbf{n}=\frac{1}{2} \\
\quad \\
\qquad \mathbf{n}=\frac{1}{3}\end{array} \\
\text { Questions: } \\
\text { a. Explain what happened to the result of } \frac{4}{3} \\
: \mathrm{n} !\end{array}$ \\
\hline
\end{tabular}

\footnotetext{
${ }^{19}$ David W. Braithwaite, Aryn A. Pyke, and Robert S. Siegler, "A Computational Model of Fraction Arithmetic," Psychological Review 124, no. 5 (2017): 603-25, https://doi.org/10.1037/rev0000072.

${ }^{20}$ Francis (Skip) Fennell and Karen Karp, "Fraction Sense: Foundational Understandings," Journal of Learning Disabilities 50, no. 6 (2017): 648-50, https://doi.org/10.1177/0022219416662030.

21 Thompson and Kaur, "Using a Multi-Dimensional Approach to Understanding to Assess Student's Mathematical Knowledge.”
} 


\begin{tabular}{|c|c|c|}
\hline & & $\begin{array}{l}\text { b. From the result of the division operation } \\
\text { in part a, which value of } n \text { shows the } \\
\text { greatest answer? }\end{array}$ \\
\hline Uses $(\mathbf{U})$ & $\begin{array}{l}\text { Applying } \\
\text { mathematical } \\
\text { operations or } \\
\text { modelling in solving } \\
\text { everyday context } \\
\text { problems }\end{array}$ & $\begin{array}{l}\text { Mr. Wahyu owns a plot of land with an area } \\
\text { of } 1 \frac{2}{3} \text { hectares, then } \frac{1}{6} \text { hectares used to build } \\
\text { a house, and the rest for the garden. } \\
\text { Therefore, how big is Mr. Wahyu's garden? }\end{array}$ \\
\hline $\begin{array}{l}\text { Reprecentation, } \\
(\mathbf{R})\end{array}$ & $\begin{array}{l}\text { Displaying } \\
\text { mathematical } \\
\text { concepts in the form } \\
\text { of graphs, pictures, or } \\
\text { symbols }\end{array}$ & $\begin{array}{l}\text { Draw a diagram that showing the results of } \\
1 \frac{2}{3}+\frac{1}{6} !\end{array}$ \\
\hline
\end{tabular}

\section{RESULTS AND DISCUSSION}

Four questions were given to students to represent the indicators of understanding the concept fractional of SPUR dimension. Below, diagram 1 presents the responses of male and female students based on the ability category in each dimension.

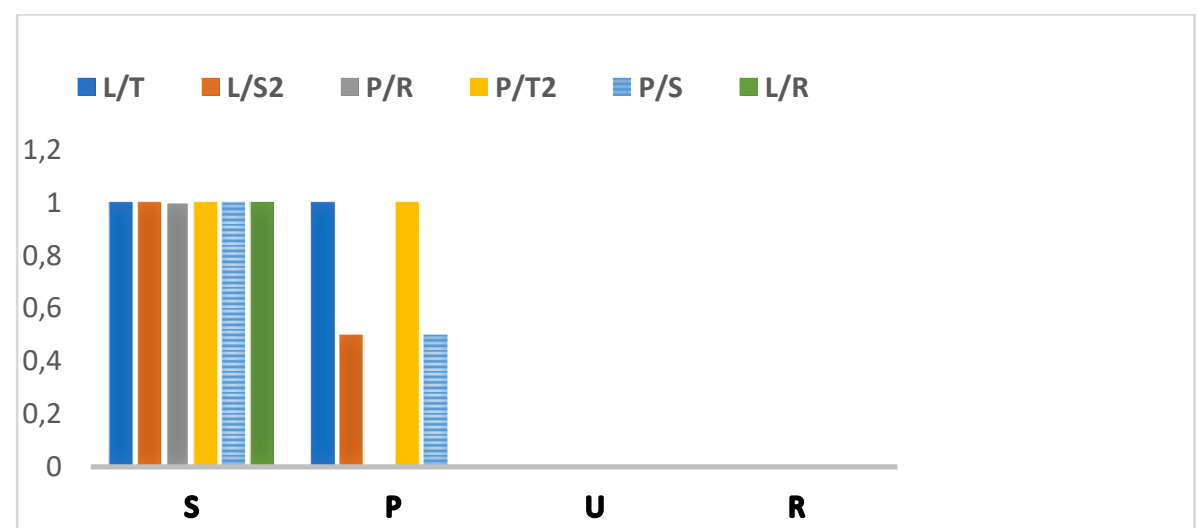

KETERANGAN: P/T: female students in hight ability; P/S: female students in medium ability ; P/R: female students in low ability; L/T: Male students in hight ability ; L/S: Male students in medium ability; L/R: female students in low ability; S: Skills; P: Property; U: Uses; R: Representation

\section{Diagram 1}

Students' responses are based on gender and ability category of The SPUR dimension.

In diagram 1, it can be seen that female and male students in the high, medium and low ability categories have not been able to solve problems on the dimensions of application ( $\mathrm{U})$ and representation $(\mathrm{R})$, but are very proficient in the dimensions of skills or procedures $(\mathrm{K})$. Several previous studies have tried to describe the reasons why students are superior in skills or procedures. Based on the teacher's report in teaching 
fractions in the classroom is more focused on troubleshooting procedures. ${ }^{22}$ Finally, it led to the familiarity of students work on the problems in the form of multiple-choice and a series of tasks procedural skills low level. ${ }^{2324}$ Even though applying procedures that have been properly trained in solving mathematical problems, it can be predicted not to help assess student knowledge. ${ }^{25}$ Supposedly, students are trained to build the solution of problems of the real world and its representation. ${ }^{26}$ Teachers need to consider applying mathematics and representation to make a major contribution in teaching mathematics, one of which is increasing higher-order thinking skills by presenting the contextual problem. ${ }^{27}$ Fuchs et al. mention another cause, namely the inability of teachers to describe the concept of fractions to the difficulties concept. ${ }^{28}$ So that the students accept the concept of fractions partially.

The following table 2 presents the analysis of the ability to understand the concept of fractions based on the dimensions.

Table 2

Analysis of student understanding of the SPUR dimension

\begin{tabular}{|c|c|c|}
\hline JK & $\begin{array}{c}\text { Ability } \\
\text { Category }\end{array}$ & Analysis based on SPUR dimension \\
\hline $\mathbf{F}$ & High & S: using the right algorithm. \\
\hline $\mathbf{E}$ & & P: using the right property-related substitution rules, the \\
\hline $\mathbf{M}$ & & operating division of fractions, fractions transform ordinary into \\
\hline $\mathbf{A}$ & & the mix and determine the value of a large fraction. \\
\hline $\mathbf{L}$ & & U: able to create a mathematical model but have not been able \\
\hline $\mathbf{E}$ & & to complete the model \\
\hline
\end{tabular}

${ }^{22}$ Amelia S. Malone and Lynn S. Fuchs, "Error Patterns in Ordering Fractions Among At-Risk Fourth-Grade Students," Journal of Learning Disabilities 50, no. 3 (May 1, 2017): 337-52, https://doi.org/10.1177/0022219416629647.

${ }^{23}$ Joan Herman and Robert Linn, "On the Road to Assessing Deeper Learning: The Status of Smarter Balanced and PARCC Assessment Consortia," CRESST Report 823 (Los Angeles: CRESST/University of California, January 2013), https://cresst.org/wp-content/uploads/R823.pdf.

${ }^{24}$ Joan Herman and Robert Linn, "On the Road to Assessing Deeper Learning: The Status of Smarter Balanced and PARCC Assessment Consortia," CRESST Report 823 (Los Angeles: CRESST/University of California, January 2013), https://cresst.org/wp-content/uploads/R823.pdf.

25 Paul F. Conway and Finbarr C. Sloane, "International Trends In Post-Primary Mathematics Education: Perspectives On Learning, Teaching And Assessment," 2005, https://ulir.ul.ie/handle/10344/5002.

${ }^{26}$ Achmetli, Schukajlow, and Rakoczy, "Multiple Solutions for Real-World Problems, Experience of Competence and Students' Procedural and Conceptual Knowledge."

27 Weni Tria Anugrah Putri and Restu Yulia Hidayatul Umah, "The Improving Of Higher-Order Thinking Skills As Information Filter For Alpha Generation," Al-Bidayah : Jurnal Pendidikan Dasar Islam 12, no. 1 (June 30, 2020): 125-38, https://doi.org/10.14421/al-bidayah.v12i1.341.

28 Amelia S. Malone and Lynn S. Fuchs, "Error Patterns in Ordering Fractions Among At-Risk Fourth-Grade Students," Journal of Learning Disabilities 50, no. 3 (2017): 337-52, https://doi.org/10.1177/0022219416629647. 


\begin{tabular}{|c|c|c|}
\hline & & $\begin{array}{l}\text { R: representing the concept in a pie chart but experiencing an } \\
\text { error in the arithmetic addition operation }\end{array}$ \\
\hline & Medium & S: using the right algorithm. \\
\hline & & $\begin{array}{l}\text { P: able to use the property of division arithmetic rules but has } \\
\text { an error comparing fraction values. }\end{array}$ \\
\hline & & $\begin{array}{l}\text { U: have not been able to solve problems in everyday contexts } \\
\text { but can change story problems in mathematical modelling. } \\
\mathbf{R} \text { : have not been able to present concepts in the form of graphs } \\
\text { or figures.. }\end{array}$ \\
\hline & Low & S: using the right algorithm. \\
\hline & & P: not able to use property \\
\hline & & U: not yet be able to make mathematical models \\
\hline & & $\begin{array}{l}\text { R: not capable of representing concepts in diagrams or } \\
\text { mathematical figures }\end{array}$ \\
\hline JK & $\begin{array}{l}\text { Ability } \\
\text { Category }\end{array}$ & Analysis based on SPUR dimension \\
\hline & High & S: using the right algorithm. \\
\hline M & & $\begin{array}{l}\text { P: using the right property-related substitution rules, the } \\
\text { operating division of fractions, fractions transform ordinary into } \\
\text { the mix and can determine the value of a large fraction.. } \\
\text { U: able to create a mathematical model but have not been able } \\
\text { to complete the model. } \\
\text { R: representing the concept in a pie chart but experiencing an } \\
\text { error in the arithmetic addition operation }\end{array}$ \\
\hline $\mathbf{A}$ & Medium & S: using the right algorithm. \\
\hline $\mathbf{L}$ & & P: have not been able to use the property or principle of \\
\hline $\mathbf{E}$ & & $\begin{array}{l}\text { fractions, especially in comparing fractions with large and small } \\
\text { values. }\end{array}$ \\
\hline & & $\begin{array}{l}\text { U: have not been able to solve problems in everyday contexts } \\
\text { but can change story problems in mathematical modelling. } \\
\text { R: represented in the form of pie and square diagrams but } \\
\text { encountered an error in the arithmetic addition operation }\end{array}$ \\
\hline & Low & S: using the right algorithm. \\
\hline & & P: not able to use property \\
\hline & & U: not able to make mathematical models \\
\hline & & $\begin{array}{l}\text { R: have not been able to represent concepts in diagrams or } \\
\text { mathematical figures }\end{array}$ \\
\hline
\end{tabular}

\section{The Understanding The Concept Of High-Ability Male And Female Students}

High-ability female and male students almost fulfilled the indicators of understanding the SPUR concept. On the application dimension, they can create a mathematical model but failed to finish the model due to an error in the arithmetic subtraction operation and the representation dimension experienced sum arithmetic operation errors. These errors can be seen in the students' answers presented in Figures 3 and 4 


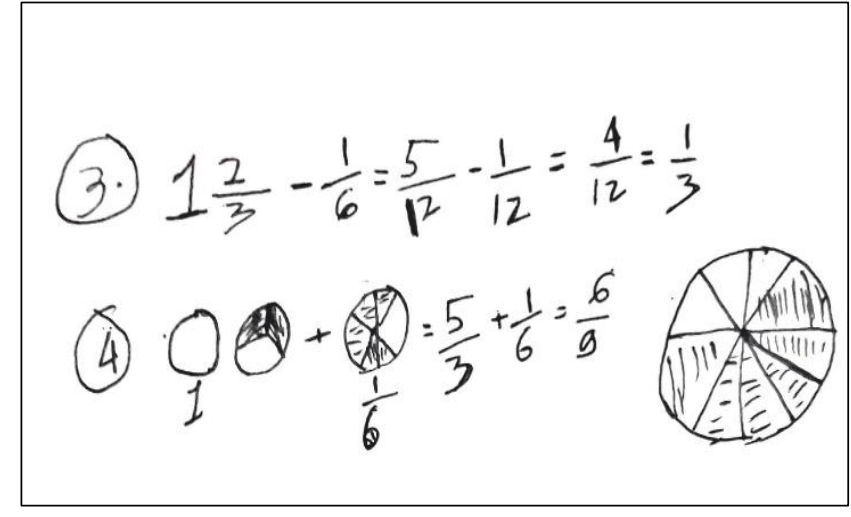

Figure 3

The answers of female students in the high category on questions number 3 and 4

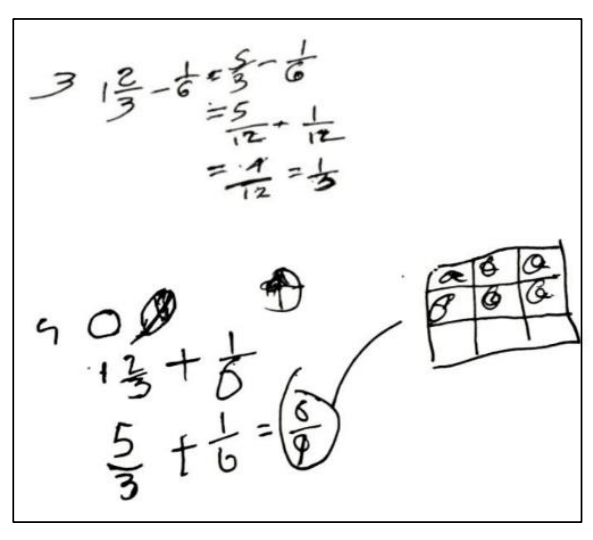

Figure 4

The answers of male students in the high category on questions number 3 and

An interesting finding, whereas in previous research, fraction division was often considered the most difficult fractional arithmetic operation for students to understand. ${ }^{29}$ In fact, in this research, they are more proficient in the division than addition and subtraction. This condition is referred to as bias integers. ${ }^{30}$ Integer bias involves arithmetic operations on the numerator and denominator separately as independent integers ${ }^{31}$ or two separate integers. ${ }^{32}$



In question number 3 , they complete step 1 is equating the denominator to find KPK 3 and 6 is 12, and then performed the subtraction operation without going through step 2. In problem-solving algorithms on Question 3, the male students more detailed descriptions. From changing mixed fractions $\left(1 \frac{2}{3}\right)$ to $\frac{5}{3}$, while the female students missed it. However, female students are neater without any meaningless scribbles on the answer

\footnotetext{
${ }^{29}$ Braithwaite, Pyke, and Siegler, "A Computational Model of Fraction Arithmetic.”

${ }^{30}$ Brianna Bentley and Michael J. Bossé, "College Students' Understanding of Fraction Operations," International Electronic Journal of Mathematics Education 13, no. 3 (2018): 233-47, https://doi.org/10.12973/iejme/3881.

${ }^{31}$ Braithwaite, Pyke, and Siegler, "A Computational Model of Fraction Arithmetic."

${ }^{32}$ Lynn S. Fuchs et al., "Fraction Intervention for Students With Mathematics Difficulties: Lessons Learned From Five Randomized Controlled Trials," Journal of Learning Disabilities 50, no. 6 (2017): 63139, https://doi.org/10.1177/0022219416677249.
} 
paper. The results of this research are contrary to the research of Romaya and Rahmawati. ${ }^{33}$

In addition, operation (Question 4) immediately sums fractions without going through steps 1 and 2, equating the denominator. In question number 4, the male student originally made representations of fractions in a circle without giving operation symbols, and he produced an honest representation. The representation of the image formed reads, "if the circle is added to the circle, it produces a box," obviously, it is a mistake. Thus, the male students of high ability have not been able to rationalize fraction operations in representation. So it is not only that high-ability male students are superior in math to women as Leder and Forgasc have described it that the gender gap favoring men is greatest among high-achieving students. ${ }^{34}$

\section{The Understanding The Concept Of Fractions Of Male And Female Students In Medium Ability}

There was no significant difference between female and male students in the medium ability category. Errors in the high student category that bias integers in addition and subtraction operations were still ongoing medium ability students. They only arrived at the skill dimension, and some were able to work on problems that measure the property, namely using the principle of division of fractions. However, they experienced an error in assessing the amount of the fractional value while the male students did not answer. From the results of the operation $\frac{4}{3}: \mathrm{n}, \mathrm{n}$ itself has various values, namely $\frac{1}{2}, \frac{1}{3}$, and $\frac{3}{4}$ the correct answers are $2 \frac{2}{3}, 4$, dan $1 \frac{7}{9}$. After that, the students were asked to determine the result with the highest value, and the female student answered $1 \frac{7}{9}$. These answers can be seen in Figures 5 and 6 below.

${ }^{33}$ Hersi Romaya and Ika Rahmawati, "Penalaran Siswa SD Kelas V dalam Pemecahan Masalah Matematika Ditinjau Berdasarkan Perbedaan Gender," Jurnal Penelitian Pendidikan Guru Sekolah Dasar 7, no. 6 (August 9, 2019), https://jurnalmahasiswa.unesa.ac.id/index.php/jurnal-penelitianpgsd/article/view/30158.

34 Gilah C. Leder and Helen J. Forgasz, "Measuring Who Counts: Gender and Mathematics Assessment," ZDM - Mathematics Education 50, no. 4 (2018): 687-97, https://doi.org/10.1007/s11858018-0939-z. 


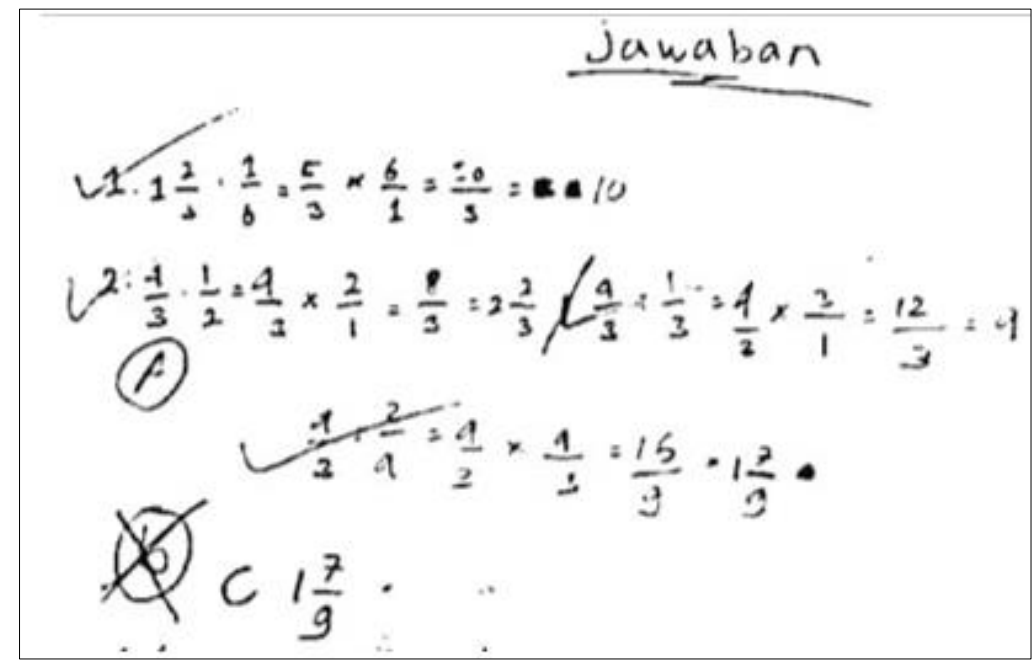

Figure 5

The answers of female students in the medium category on questions number 1 and 2

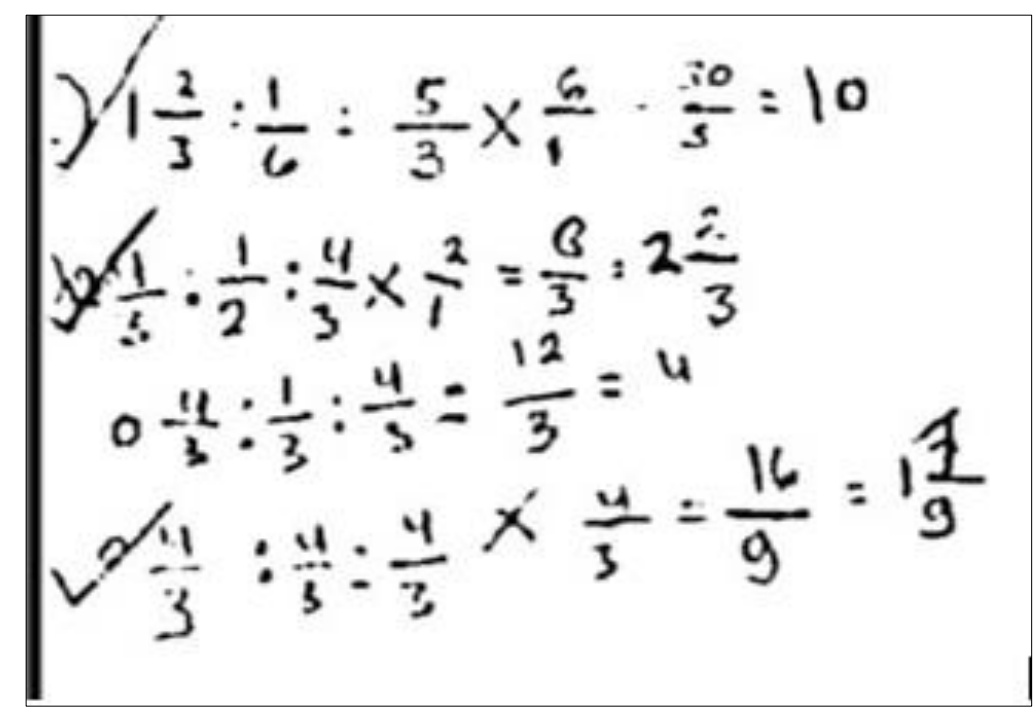

Figure 6

The answers of male students in the medium category on questions number 1 and 2

According to Malone, students often make this error up to the upper elementary grades, namely using the property of integers to fractions (integer bias). ${ }^{35}$ Students focus on the value of the denominator and assume that the greater the value of the denominator, the greater the value of the fraction. Whereas the exact property is that the more a unit is divided into more (larger denominators), the smaller each part or fraction value is smaller. 2017.

\footnotetext{
${ }^{35}$ Malone and Fuchs, "Error Patterns in Ordering Fractions Among At-Risk Fourth-Grade Students,"
} 
The Understanding The Concept Of Fractions Of Low-Ability On Male And Female Students

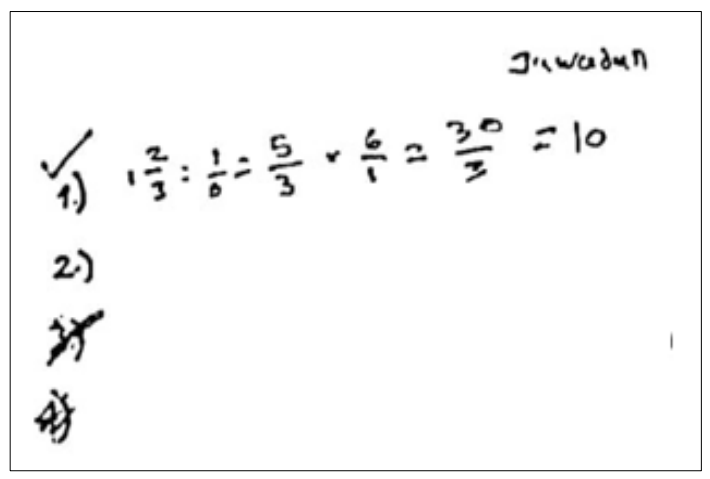

Figure 7

The answer of female students in the low category on question number 1

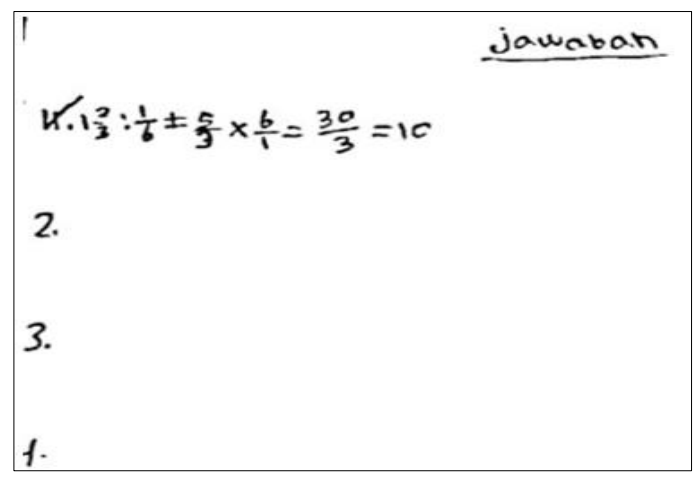

Figure 8

The answer of male students in the low category on question number 1

In the low-ability students, both men and women can only answer question number 1 (skills/procedures), shown in Figures 7 and 8. Thus, the female students and male madrasah in each category can understand the concept of fractions equivalent in SPUR dimensions.

This finding is consistent with research regarding gender math skills by Legowo in elementary school that there is no gender effect on students' ability to think creatively mathematically. ${ }^{36}$ A decade ago, Sara M. Lindberg et al. carried out meta-analysis research and resulted in the same findings, namely for primary school children, no gender effect, but a moderator variable. ${ }^{37}$ For example, the effect of working memory. ${ }^{38}$ Leder and Forgasz concluded that the ability of men and women could excel in each of the elements depending on the domain of the mathematics content being tested and the assessment instrument used. ${ }^{39}$

Gender differences affect math performance is predominantly found in middle school students and universities than elementary school students. ${ }^{40}$ Kersey also supports

${ }^{36}$ Yogi Ageng Sri Legowo, "Pengaruh Gender Terhadap Kemampuan Berpikir Kreatif Matematis Siswa Di Sekolah Dasar," WASPADA (Jurnal Wawasan Pengembangan Pendidikan) 7, no. 1 (2020): 5661, https://core.ac.uk/download/pdf/322612239.pdf.

37 Sara M. Lindberg et al., "New Trends in Gender and Mathematics Performance: A MetaAnalysis," Psychological Bulletin 136, no. 6 (2010): 1123-35, https://doi.org/10.1037/a0021276.

${ }^{38}$ Fuchs et al., "Fraction Intervention for Students With Mathematics Difficulties: Lessons Learned From Five Randomized Controlled Trials."

${ }^{39}$ Leder and Forgasz, "Measuring Who Counts: Gender and Mathematics Assessment."

${ }^{40}$ Susana Rodríguez Martínez et al., "Gender Differences in Mathematics Motivation: Differential Effects on Performance in Primary Education,” 2020, https://doi.org/10.3389/fpsyg.2019.03050; Szczygiel, 
the previous statement that it is difficult to measure gender differences in children; statistically, both have equal ability in the arithmetic ${ }^{41}$ of their early mathematical skills at the start of education.

Several things contribute to gender stereotypes in teaching mathematics, which seem trivial but significant effects, such as setting groups and teachers' interaction towards male students. Usually, in teaching mathematics, teachers are more dominant in building interactions with male students than female students to create good classroom management. A belief is that male students do many other or disruptive movements to be directed to them more than female students. Female students tend capable of regulating themselves well and doing their jobs. So that female students are less involved in the communication of mathematics teaching in the classroom. ${ }^{42}$

Gender stereotypes that generally develop in the community "men are more talented than women at math" can be a threat to female students; this conviction can result in a lack of confidence of female students in mathematics teaching. ${ }^{43}$ Increases anxiety and results in decreased performance in solving problem-solving. Therefore, understanding the concept of men and women must be strengthened in the four dimensions of SPUR without distinguishing each other. Moreover, considering the errors that arise, such as integer bias and misrepresentation, can be a teacher's figure in improving subsequent teaching. So in the future, teachers are expected to construct questions far from gender bias and build communication in teaching mathematics to both.

\section{CONCLUSION}

Understanding fractions in SPUR dimensions are similar between female and male students in the same ability category. However, students at all levels achieve a different dimension. Based on the analysis results, male and female equally high category

\footnotetext{
"How to Measure Math Anxiety in Young Children?," 2019; Khatoon Vakili and Zinat alsadat Pourrazavy, "Comparing the Math Anxiety of Secondary School Female Students in Groups (Science and Mathematical Physics) Public Schools," International Journal of Environmental and Science Education 12, no. 4 (2017): 755-61, https://eric.ed.gov/?id=EJ1144820.

41 Alyssa J. Kersey et al., "No Intrinsic Gender Differences in Children's Earliest Numerical Abilities," Npj Science of Learning 3, no. 1 (2018), https://doi.org/10.1038/s41539-018-0028-7.

${ }^{42}$ Marcus Samuelsson and Joakim Samuelsson, “Gender Differences In Boys' And Girls' Perception Of Teaching And Learning Mathematics," Open Review of Educational Research 3, no. 1 (January 1, 2016): 18-34, https://doi.org/10.1080/23265507.2015.1127770.

${ }^{43}$ Zachary Estes and Sydney Felker, "Confidence Mediates the Sex Difference in Mental Rotation Performance," Archives of Sexual Behavior 41, no. 3 (2012): 557-70, https://doi.org/10.1007/s10508-0119875-5.
} 
reached the dimensions of skills and property. Male and female students in the medium and low categories achieved skills. While the dimensions of the application (U) and the representation $(\mathrm{R})$ are understood partially by high-ability students and currently, they can create a mathematical model of narrative matter, but failed in the completion of the model due to refractive error of the property integer on fractions. They perform arithmetic operations on the numerator and denominator separately as if they were independent or separate integers. There is an interesting finding the male students of high ability are experiencing errors in rationalization representation.

Moreover, in the future, students will actively develop an understanding of mathematical concepts regardless of gender stereotypes that develop in society. Teachers can facilitate them in teaching mathematics by presenting questions that avoid gendering bias, questions that measure understanding of the concept of skills, the use of the property, the application of mathematics and its representation (SPUR) and not only focused on procedural troubleshooting. As well as in teaching, teachers should establish communication in teaching mathematics to students male and female.

The limitation of this research is the lack of supporting data in this case, the results of interviews to explore the study. So, for further researchers that reviews from various data sources is very much needed. Besides, it is highly recommended to review gender differences based on the form of math tests.

\section{ACKNOWLEDGMENTS}

The authors are grateful to the MI (Islamic Elementary) Wathoniyah teachers in Indramayu Regency who has helped in this research.

\section{DECLARATION OF CONFLICTING INTERESTS}

The author/s declared no potential conflicts of interest with respect to the research, authorship, and/or publication of this article.

\section{FUNDING}

There is no institution funding this research. This research was conducted independently by the authors. 


\section{ORCID iD}

Hajra Yansa iD https://orcid.org/0000-0001-6443-499X

Nurhayati

https://orcid.org/0000-0001-9708-077X

\section{REFERENCES}

Achmetli, Kay, Stanislaw Schukajlow, and Katrin Rakoczy. "Multiple Solutions for RealWorld Problems, Experience of Competence and Students' Procedural and Conceptual Knowledge." International Journal of Science and Mathematics Education 17, no. 8 (2018): 1605-25. https://doi.org/10.1007/s10763-018-99365.

Bentley, Brianna, and Michael J. Bossé. "College Students' Understanding of Fraction Operations." International Electronic Journal of Mathematics Education 13, no. 3 (2018): 233-47. https://doi.org/10.12973/iejme/3881.

Braithwaite, David W., Aryn A. Pyke, and Robert S. Siegler. "A Computational Model of Fraction Arithmetic." Psychological Review 124, no. 5 (2017): 603-25. https://doi.org/10.1037/rev0000072.

Conway, Paul F., and Finbarr C. Sloane. "International Trends In Post-Primary Mathematics Education: Perspectives On Learning, Teaching And Assessment," 2005. https://ulir.ul.ie/handle/10344/5002.

Dilla, Siska Chindy, Wahyu Hidayat, and Euis Eti Rohaeti. "Faktor Gender Dan Resiliensi Dalam Pencapaian Kemampuan Berpikir Kreatif Matematis Siswa SMA." Journal of Medives: Journal of Mathematics Education IKIP Veteran Semarang 2, no. 1 (2018): 129. https://doi.org/10.31331/medives.v2i1.553.

Estes, Zachary, and Sydney Felker. "Confidence Mediates the Sex Difference in Mental Rotation Performance." Archives of Sexual Behavior 41, no. 3 (2012): 557-70. https://doi.org/10.1007/s10508-011-9875-5.

Fennell, Francis (Skip), and Karen Karp. "Fraction Sense: Foundational Understandings." Journal of Learning Disabilities 50, no. 6 (2017): 648-50. https://doi.org/10.1177/0022219416662030.

Fuchs, Lynn S., Amelia S. Malone, Robin F. Schumacher, Jessica Namkung, and Amber Wang. "Fraction Intervention for Students With Mathematics Difficulties: Lessons Learned From Five Randomized Controlled Trials.” Journal of Learning $\begin{array}{llllll}\text { Disabilities } & 50, & \text { no. } & 6 & \text { (2017): }\end{array}$ https://doi.org/10.1177/0022219416677249.

Gherasim, Loredana Ruxandra, Simona Butnaru, and Cornelia Mairean. "Classroom Environment, Achievement Goals and Maths Performance: Gender Differences." Educational Studies 39, no. 1 (February 1, 2013): 1-12. https://doi.org/10.1080/03055698.2012.663480.

Gravemeijer, Koeno, Michelle Stephan, Cyril Julie, Fou Lai Lin, and Minoru Ohtani. "What Mathematics Education May Prepare Students for the Society of the Future?" International Journal of Science and Mathematics Education 15 (2017): 105-23. https://doi.org/10.1007/s10763-017-9814-6. 
Herman, Joan, and Robert Linn. "On the Road to Assessing Deeper Learning: The Status of Smarter Balanced and PARCC Assessment Consortia." CRESST Report 823. Los Angeles: CRESST/University of California, January 2013. https://cresst.org/wp-content/uploads/R823.pdf.

Kamoru, Usman, and Olosunde Gbolagade Ramon. "Influence of Self-Concept, Study Habit and Gender on Attitude and Achievement of Secondary School Students in Mathematics." Journal for Leadership and Instruction 16, no. 1 (2017): 49-52. https://eric.ed.gov/?id=EJ1159874.

Kersey, Alyssa J., Emily J. Braham, Kelsey D. Csumitta, Melissa E. Libertus, and Jessica F. Cantlon. "No Intrinsic Gender Differences in Children's Earliest Numerical Abilities." Npj Science of Learning 3, no. 1 (2018). https://doi.org/10.1038/s41539-018-0028-7.

Khaw, Alina Han Ron, and Berinderjeet Kaur. "A Study of Mathematics Homework in Singapore Secondary Two Classrooms," 2017. https://repository.nie.edu.sg//handle/10497/19438.

Leder, Gilah C., and Helen J. Forgasz. "Measuring Who Counts: Gender and Mathematics Assessment." ZDM - Mathematics Education 50, no. 4 (2018): 68797. https://doi.org/10.1007/s11858-018-0939-z.

Legowo, Yogi Ageng Sri. "Pengaruh Gender Terhadap Kemampuan Berpikir Kreatif Matematis Siswa Di Sekolah Dasar." WASPADA (Jurnal Wawasan Pengembangan Pendidikan) 7, no. 1 (2020): 56-61. https://core.ac.uk/download/pdf/322612239.pdf.

Lindberg, Sara M., Janet Shibley Hyde, Jennifer L. Petersen, and Marcia C. Linn. "New Trends in Gender and Mathematics Performance: A Meta-Analysis." Psychological Bulletin 136, no. 6 (2010): 1123-35. https://doi.org/10.1037/a0021276.

Malone, Amelia S., and Lynn S. Fuchs. "Error Patterns in Ordering Fractions Among AtRisk Fourth-Grade Students." Journal of Learning Disabilities 50, no. 3 (May 1, 2017): 337-52. https://doi.org/10.1177/0022219416629647.

National Council of Teachers of Mathematics (NCTM). "Principles to Actions : Ensuring Mathematical Success for All (Executive Summary)." NCTM, 2014. https://www.nctm.org/uploadedFiles/Standards_and_Positions/PtAExecutiveSu mmary.pdf.

Patricia, Firda Alfiana, and Kenys Fadhilah Zamzam. "Diskalkulia (Kesulitan Matematika) Berdasarkan Gender Pada Siswa Sekolah Dasar Di Kota Malang." AKSIOMA: Jurnal Program Studi Pendidikan Matematika 8, no. 2 (2019): 288. https://doi.org/10.24127/ajpm.v8i2.2057.

Putri, Niva Ramadhani, Enni Astari Nursyahban, Gida Kadarisma, and Euis Eti Rohaeti. "Analisis Kemampuan Pemahaman Matematik Siswa SMP Ppada Materi Segitiga Dan Segiempat." In Prosiding Seminar Nasional Matematika Dan Pendidikan $\begin{array}{llll}\text { Matematika Sesiomadika 2019, } 2019 . & \text { 2:1015-26, }\end{array}$ https://doi.org/10.22460/jpmi.v1i2.p157-170. 
Putri, Weni Tria Anugrah, and Restu Yulia Hidayatul Umah. "The Improving Of HigherOrder Thinking Skills As Information Filter For Alpha Generation." Al-Bidayah : Jurnal Pendidikan Dasar Islam 12, no. 1 (June 30, 2020): 125-38. https://doi.org/10.14421/al-bidayah.v12i1.341.

Risnamajasari, Risnamajasari. "Profil Pemecahan Masalah Matematika Dikaitkan Dengan Aspek Multidimensi SPUR Pada Siswa Berprestasi Di SMP Islam Athirah." Masters, Pascasarjana, 2017. http://eprints.unm.ac.id/12735/.

Rodríguez Martínez, Susana, Bibiana Regueiro Fernández, Isabel Piñeiro Aguín, Iris Estévez Blanco, and Antonio Valle Arias. "Gender Differences in Mathematics Motivation: Differential Effects on Performance in Primary Education," 2020. https://doi.org/10.3389/fpsyg.2019.03050.

Romaya, Hersi, and Ika Rahmawati. "Penalaran Siswa SD Kelas V dalam Pemecahan Masalah Matematika Ditinjau Berdasarkan Perbedaan Gender." Jurnal Penelitian Pendidikan Guru Sekolah Dasar 7, no. 6 (August 9, 2019). https://jurnalmahasiswa.unesa.ac.id/index.php/jurnal-penelitianpgsd/article/view/30158.

Samuelsson, Marcus, and Joakim Samuelsson. “Gender Differences In Boys' And Girls' Perception Of Teaching And Learning Mathematics." Open Review of Educational Research 3, no. 1 (January 1, 2016): 18-34. https://doi.org/10.1080/23265507.2015.1127770.

Suurtamm, Christine, dennise R. Thompson, Rae Young Kim, Leonora Diaz Moreno, Nathalie Sayac, Stanislaw Schukajlow, Edward Silver, Sefan Ufer, and Pauline Vos. Assessment in Mathematics Education Large-Scale Assesment and Classroom Assessment. Encyclopedia of Mathematics Education. Hamburg, 2016. https://doi.org/10.1007/978-94-007-4978-8_61.

Szczygieł, Monika. "How To Measure Math Anxiety In Young Children? Psychometric Properties Of The Modified Abbreviated Math Anxiety Scale For Elementary Children (MAMAS-E).” Polish Psychological Bulletin 50 (December 31, 2019): 303-15. https://doi.org/10.24425/ppb.2019.131003.

Thi, Ho, and Minh Phuong. "On the Procedural-Conceptual Based Taxonomy and Its Adaptation to the Multi-Dimensional Approach SPUR to Assess Students ' Understanding Mathematics." American Journal of Educational Research 7, no. 3 (2019): 212-18. https://doi.org/10.12691/education-7-3-4.

Thompson, dennise R., and Berinderjeet Kaur. "Using a Multi-Dimensional Approach to Understanding to Assess Student's Mathematical Knowledge." In Assessment in the Mathematics Classroom Yearbook 2011, Association of Mathematics Educators, edited by Berinderjeect Kaur and Wong Khoon Yoong, 91-111. Singapore: World Scientific Publishing Company, 2011.

Vakili, Khatoon, and Zinat alsadat Pourrazavy. "Comparing the Math Anxiety of Secondary School Female Students in Groups (Science and Mathematical Physics) Public Schools." International Journal of Environmental and Science Education 12, no. 4 (2017): 755-61. https://eric.ed.gov/?id=EJ1144820.

Weldeana, Hailu Nigus, and Desta Berhe Sbhatu. "Portfolio of Evidence : An Assessment Tool in Promoting Geometry Achievement among Teacher Education College 
Students." Journal of Mathematics Science and Technology Education 8223, no. 6 (2017): 1981-2004. https://doi.org/10.12973/eurasia.2017.01210a.

Zeeuw, Audrey De, Tara Craig, and Hye Sun You. "Assessing Conceptual Understanding in Mathematics." Proceedings - Frontiers in Education Conference, FIE, 2013, 1742-44. https://doi.org/10.1109/FIE.2013.6685135. 